\title{
MARKET TO BOOK VALUE, FIRM SIZE, AND THE UNDERPRICING OF INDONESIAN INITIAL PUBLIC OFFERINGS
}

\author{
Marmono Singgih $^{1}$, Veryantika Putri Pricilia ${ }^{2}$, Eka Lavista ${ }^{3}$ \\ ${ }^{1}$ Faculty of Economics and Business Universitas Jember, \\ ${ }^{2}$ Private employee, ${ }^{3}$ STIE Widyagama Lumajang
}

\begin{abstract}
The focus of this study is to analyze whether market to book value ratio and firm size determine the extent of initial return rate of firms making initial public offering (IPO). The subject of the study is all IPO from the period of 2007-2016. There are 173 IPOs used as sample. It uses two measurements of initial returns, the raw return and the market adjusted return. As documented in many studies, there is evidence that on average the Indonesian IPO experience underpricing. Results using regression analysis show that market to book value ratio and firm size have negative and significant effect on both of the measures for initial return. This finding asserts the importance of understanding the market to book value ratio in the valuation of Indonesia IPOs.
\end{abstract}

Keywords: market to book value ratio, firm size, initial return rate, IPO

\section{Introduction}

An Initial Public Offering (IPO) is an initial sale of the company's stocks to the public on the stock exchange. One of the most difficult parts in the IPO is the determination of the offering price. Issuers and underwriters must agree to determine at what price and how many stocks are to be sold. The error in the pricing could lead to failure in stock offerings. If the price is set too high, there is a possibility that the stock will not sell and both parties, the underwriter and the shareholder will be affected. Conversely, if the stock price is set too cheap, the stock will sell easily but the funds obtained by the owner would be less.

\footnotetext{
*Corresponding Author.

e-mail: marmono.singgih@gmail.com
} 
To make an IPO, a company must set up a prospectus. The prospectus must obtain approval from the Indonesian stock exchange governing body, Otoritas Jasa Keuangan. The prospectus contains both accounting and non-accounting information. This information must contain a description of the company. Many information in the prospectus can be used as a signal by companies, which is useful for the investors for assessment of the IPO.

Empirical evidence shows that on average the IPO is experiencing a phenomenon known as underpricing (Loughran et al., 1995). Underpricing occurs when the stock price on the secondary market is higher than the offering price. Investors expect underpricing, because that means profit for them. On the contrary, the initial owners of the company will lose wealth, which means there is money left on the table (Ritter, 1991).

To ascertain that the IPO is successful, the company hires underwriters to sell the stocks. There are two types of guarantees that are commonly known, the full commitment and the best effort. In the full commitment case, the underwriter is fully responsible for the sales of the stocks and must be ready to buy the unsold stocks. If the price set is too high, then the stocks offered cannot be sold easily and the underwriter must bear the consequences. On the contrary, if the price is set too low, the stocks will be sold easily and the underwriter will benefit, but the company owner will lose the potential to get higher proceeds.

One way to assess the fairness of stock prices during an IPO is by analyzing the price to book value of equity ratio (PBVER). Investors may compare the PBVER of the selling company with PBVER of other companies in the same industry. In the context of the IPO, the PBVER value can be calculated from the ratio of the stock price offered in the primary market to the value of equity per share. We can call this ratio as a market to book value ratio (MBVR). MBVR ratio shows how much money the investors are willing to pay for each company's equity book value. At the time of the IPO, the market ratio to book value can be seen from the comparison of the stock offering price and the nominal value or par value of the stocks.

MBVR value can be an indicator of the risk involved in an IPO. That is, if the company's MBVR value is too high, then the owner and underwriter will set a high selling price relative to the par value of the stocks. The wealth of the initial owners will increase if the stock price is high. However, this can have an 
impact on the likelihood that the stocks will not receive high demand. Conversely, if the company's MBVR value is too low, the wealth of the initial owners will be lower although the selling of the stocks could be successful. That means MBVR can be used as an indicator of how risky the company is.

Another variable that can measure the risk of an IPO is the size of the stocks offered. This is known as gross proceeds. This is the gross receipt from the stock offering before being deducted by costs of selling the stocks, such as commissions for underwriters. Ritter (1991) explicitly showed that an IPO with a high share offer value on average will tend to experience lower levels of underpricing than an IPO with a low share offer value. This is also consistent with the size anomaly. Gumanti (2011) stated that the size effect is a situation where stocks of small-scale companies tends to produce a higher return than that of a large-scale company. This is because small companies tend to face more risks than a large one.

A number of studies have been conducted to examine the effect of MBV and firm size on the level of IPO initial return. MBVR is found to have a positive effect on the initial rate of return (Michaely and Shaw, 1995), but Gounopoulos et al. (2013) reported a negative effect. The same thing is also found in the influence of firm size on initial returns (Bhabra and Pettway, 2003; Gu, 2003; Schenone, 2004; Gabriela, 2013). However, Yolana and Martani (2005), Bowen et al. (2008), Kristiantari (2013), and Wiguna and Yadnyana (2015) reported negative influences. The difference between the results of the researches is interesting to be used as a starting point for re-analyzing the effect of MBVR and firm size on the initial rate of return in the IPO in Indonesia by using relatively more recent data with a longer ime horizon.

This study analyzes the companies that did an IPO in Indonesia Stock Exchange in 2007-2016. It examines the effect of MBVR and firm size on the initial return level. A total of 173 companies were analyzed. The results showed that MBVR had a positive effect while firm size had a negative effect. This finding is in accordance with predictions.

This paper is arranged as follows: section two contains a review of the theory and the development of the hypotheses; section three presents research methods followed by the results of the research and discussion. The final section concludes the study. 


\section{Literature Review}

Initial return is the difference between initial offering price and the closing price of the first day of trading on the secondary market. There is mounting evidence showing that on average the IPO is underpriced (Ritter, 1991). That is, on average, the share price on the secondary market is higher than the offering price. There have been many theories proposed to explain why the IPO is underpriced, on average. As consequence, there are many factors known as the determinants of IPO underpricing. Table 1 presents a summary of previous studies.

Table 1 Summary of Research on Underpricing Determinants

\begin{tabular}{|c|l|l|}
\hline No. & \multicolumn{1}{|c|}{ Researcher (Year) } & \multicolumn{1}{c|}{ Results } \\
\hline 1 & $\begin{array}{l}\text { Michaely and Shaw } \\
(1995)\end{array}$ & $\begin{array}{l}\text { Market to book value ratio, auditor reputation, and } \\
\text { underwriter reputation have a positive effect }\end{array}$ \\
\hline 2 & $\begin{array}{l}\text { Bhabra and Pettway } \\
(2003)\end{array}$ & $\begin{array}{l}\text { Time of offering, firm size, free cash flow, underwriter } \\
\text { reputation, and number of risks have a positive effect }\end{array}$ \\
\hline 3 & Gu (2003) & $\begin{array}{l}\text { Firm size has a positive effect, state ownership has a nega- } \\
\text { tive effect }\end{array}$ \\
\hline 4 & Schenone (2004) & Firm size has a positive effect \\
\hline 5 & Gabriela (2013) & $\begin{array}{l}\text { Firm size and auditor reputation have a positive effect. } \\
\text { The value of the stock offering does not have effect }\end{array}$ \\
\hline 6 & $\begin{array}{l}\text { Gounopoulos et al. } \\
(2013\end{array}$ & $\begin{array}{l}\text { State ownership has a positive effect, whereas market to } \\
\text { book value ratio has a negative effect }\end{array}$ \\
\hline 7 & Kristiantari (2013) & $\begin{array}{l}\text { Underwriter reputation and company size, and the pur- } \\
\text { pose of using funds for investment have a negative effect }\end{array}$ \\
\hline 8 & $\begin{array}{l}\text { Wiguna and Yadnyana } \\
(2015)\end{array}$ & $\begin{array}{l}\text { Financial leverage has a positive effect, firm size and } \\
\text { auditor reputation have a negative effect }\end{array}$ \\
\hline
\end{tabular}

Underpricing is a reward for potential investors who are able to accurately predict IPO values (Spat and Srivastava, 1991). One way of setting the offering price of IPO is by looking at the market price of comparable companies. Companies are viewed favorably by investors if the stocks are sold with high MBVR. In other words, the higher the MBVR value of the company making the initial public offering, the higher is the potential level of underpricing. Thus, MBVR can be used as the measure of IPO risk.

MBVR is an indicator to measure company performance. This ratio can be used as a measurement tool to assess the success rate of an IPO. It is almost 
certain that each IPO is always sold above its nominal value or par value. If the value of this ratio increases, then the stock price offered will be more expensive. If the quality of the IPO is indeed good, investors will still buy the stocks. If the stock price is set correctly, ideally there will be no continuous price rise in the secondary market. If this happens, the stock market can approach the efficient form of the semi-strong (Gumanti and Utami, 2002). That is, prices that occurred in the market reflect the quality of information.

Another factor that can be used the measure of riskiness of IPO is the size of the IPO. This is what we know as the firm size. It can be measured in a number of ways. For example, the size of the company can be expressed in terms of total assets, total sales, profit level, or market capitalization value. If the size of the company is expressed in total assets, then it can be said that companies with large total assets are companies that are old and established. Companies with large assets are often regarded as established companies, long operating, and able to withstand all kinds of conditions (Hartono, 2000; Gumanti, 2005). The size of the company could be used to determine how big the level of investor trust is (Sulistio, 2005). In other words, the larger the size of a company, the more information is available and accessible. All of this will help investors to do better and to make more accurate analysis, thereby reducing the potential for estimation errors.

The size of the company can be used as an indicator by investors in investing seen from the level of risk of the company. Small companies will tend to face more risk than large companies, because small companies have a greater operating risk. In addition, information about small companies is less available. This lack of information makes small companies face more risk. The magnitude of the risk of investing in a small company that conducts an IPO will also have an impact on the initial return that is more acceptable to investors.

Companies that are considered good by investors are sold with high MBVR. The higher the MBVR, the higher is the investor's assessment of the company. If a company has high value according to the investor, then price stock is becoming increasingly expensive on the market so that it has an impact on stock returns. The share price of an IPO company that experiences an increase in the secondary market will give investors the advantage of an initial return. Michaely and Shaw (1995) stated that the market to book value ratio has a 
significant positive effect on the IPO initial return. Based on previous theories and research, the proposed hypothesis is as follows:

$\mathrm{H}_{1}$ : Market to book value ratio has positive effect on the level of underpricing.

Investors consider the size of the company to make decisions regarding investment. In the case of IPO, the firm size is proxied by either the total asset or gross proceeds. The size effect anomaly shows that small sized companies' returns are greater than the returns provided by large companies (Mar'ati, 2013). The size of the company can be used as an indicator by investors in investing, seen from the risk level of the company. Small companies tend to be more risky than large companies, because small companies have a greater operating risk. As consequence, small companies are expected to have greater initial return. Thus, it is predicted that smaller IPO will be riskier than larger IPO, which means negative relationship exists between the size of the firm and the level of underpricing. Yolana and Martani (2005), Bowen et al. (2008), Kristiantari (2013), and Wiguna and Yadnyana (2015), amongst others, reported that firm size has significant negative effect on initial return. Based on previous theories and research, the proposed hypothesis is as follows:

$\mathrm{H}_{2}$ : Company size has negative effect on the level of underpricing.

\section{Research Method}

The population in this study are all companies making IPOs on the Indonesia Stock Exchange from 2007-2016. The selected IPOs must satisfy the following criteria:

1. The company has financial statement data in IDR to avoid bias in carrying out the conversion, and

2. The company's prospectus must be accessible, as we have to obtain data about the price of the stock offering, nominal value, total assets, and value of the stock offered.

Initial return is measured based on the difference between the closing stock price on the first day on the secondary market and the offering stock price. The initial return calculation can also be done with a market-adjusted return (MAR). The initial return formula is as follows: 
$\mathrm{IR}=\frac{\mathrm{P}_{1}-\mathrm{P}_{0}}{\mathrm{P}_{0}}$

Market adjusted return (MAR) is calculated using the following formula:

$\operatorname{MAR}=\left(\frac{\mathrm{P}_{1}-\mathrm{P}_{0}}{\mathrm{P}_{0}}\right)-\left(\frac{\mathrm{CSI}_{1}-\mathrm{CSI}_{0}}{\mathrm{CSI}_{0}}\right)$

The notation IR in the formula is the initial return. The notation MAR is the market adjusted return. $\mathrm{P}_{1}$ is the stock price on the first day of the public offering. $\mathrm{P}_{0}$ is the stock offering price. $\mathrm{CSI}_{1}$ is the composite stock price index on the first day of the stock offering. $\mathrm{CSI}_{0}$ is the composite stock price index the day before the opening day of the public offering of stocks.

Market to book value ratio (MBVR) is measured by comparing the offering price of stock over the book value of equity per share. Firm size is measured as the value of total assets in the last year prior to the year of IPO. Another indicator of firm size is the gross proceeds from the issue. Firm size is expressed in a natural logarithm of total assets and gross proceeds.

To test the hypotheses, the following multiple regression analysis model are used:

$\mathrm{IR}_{i}=\alpha+\beta_{1} \mathrm{MBVR}_{i}+\beta_{2} \mathrm{FSi}+\varepsilon_{i}$

$\mathrm{MAR}_{i}=\alpha+\beta_{1} \mathrm{MBVR}_{i}+\beta_{2} \mathrm{FS}_{i}+\varepsilon_{i}$

\section{Result and Discussion}

\subsection{Description of Data}

Over the period of analysis (2007-2016), there are 209 companies which went public in the Indonesia Stock Exchange (IDX), which are the population of the study. A total of 173 IPOs met the selection criteria. The sample selection process is presented in Table 2 .

Table 2 Research Sample Selection Process

\begin{tabular}{lc}
\hline \multicolumn{1}{c}{ Information } & $\begin{array}{c}\text { Number of } \\
\text { Companies }\end{array}$ \\
\hline Number of IPOs for the period 2007-2016. & 209 \\
Financial statement data uses foreign currency (other than rupiah). & $(15)$ \\
Prospectus is not accessible. & $(21)$ \\
\hline Final sample & 173 \\
\hline
\end{tabular}


Table 3 presents summary levels of initial returns and market adjusted returns. Year 2013 is the year with the largest number of IPOs, of which there are 30 IPOs. The lowest average initial return is $4.5 \%$, which is in 2009 . The highest average initial return is found in year 2007, with a value of $27.6 \%$. Qualitatively similar findings are documented for the market adjusted average initial return. The table clearly shows that the average initial return and adjusted market return is $19.6 \%$ and $19.7 \%$, respectively. This means that on average, the level of underpricing of the companies under this study is $19.6 \%$, which is higher compared to other studies using the Indonesian setting.

Table 3 Classification of Companies Based on Year of IPO

\begin{tabular}{|c|c|c|c|c|c|c|c|c|c|c|c|}
\hline \multirow{2}{*}{ No. } & \multirow{2}{*}{ Year } & \multirow{2}{*}{ Population } & \multirow{2}{*}{$\%$} & \multirow{2}{*}{ Sampel } & \multirow{2}{*}{$\%$} & \multicolumn{3}{|c|}{ Initial Return } & \multicolumn{3}{|c|}{ Market Adjusted Return } \\
\hline & & & & & & Mean & Min. & Max. & Mean & Min. & Max. \\
\hline 1 & 2007 & 22 & 10.53 & 20 & 11.56 & 0.276 & -0.686 & 0.700 & 0.271 & -0.696 & 0.704 \\
\hline 2 & 2008 & 19 & 9.09 & 13 & 7.51 & 0.153 & -0.287 & 0.700 & 0.169 & -0.243 & 0.711 \\
\hline 3 & 2009 & 13 & 6.22 & 10 & 5.78 & 0.045 & -0.181 & 0.573 & 0.044 & -0.184 & 0.560 \\
\hline 4 & 2010 & 23 & 11.00 & 23 & 13.29 & 0.274 & -0.016 & 0.700 & 0.272 & -0.021 & 0.689 \\
\hline 5 & 2011 & 25 & 11.96 & 23 & 13.29 & 0.072 & -0.261 & 0.550 & 0.072 & -0.268 & 0.534 \\
\hline 6 & 2012 & 22 & 10.53 & 18 & 10.40 & 0.260 & 0.000 & 0.695 & 0.263 & -0.006 & 0.696 \\
\hline 7 & 2013 & 30 & 14.35 & 23 & 13.29 & 0.178 & -0.173 & 0.694 & 0.181 & -0.211 & 0.717 \\
\hline 8 & 2014 & 24 & 11.48 & 20 & 11.56 & 0.261 & -0.162 & 0.700 & 0.262 & -0.156 & 0.713 \\
\hline 9 & 2015 & 16 & 7.66 & 13 & 7.51 & 0.251 & -0.031 & 0.700 & 0.255 & -0.032 & 0.692 \\
\hline 10 & 2016 & 15 & 7.18 & 10 & 5.78 & 0.183 & -0.087 & 0.695 & 0.179 & -0.088 & 0.691 \\
\hline & otal & 209 & 100 & 173 & 100 & 0.196 & -0.686 & 0.700 & 0.197 & -0.696 & 0.717 \\
\hline
\end{tabular}

Table 4 Classification of Companies by Sector Type

\begin{tabular}{|c|c|c|c|c|c|c|c|c|c|c|c|}
\hline \multirow{2}{*}{ No. } & \multirow{2}{*}{ Type of Industry } & \multirow{2}{*}{ Population } & \multirow{2}{*}{$\%$} & \multirow{2}{*}{ Sample } & \multirow{2}{*}{$\%$} & \multicolumn{3}{|c|}{ Initial Return } & \multicolumn{3}{|c|}{ Market Adjusted Return } \\
\hline & & & & & & Mean & Min. & Max. & Mean & Min. & Max. \\
\hline 1. & Agriculture & 12 & 5.74 & 10 & 5.78 & 0.098 & -0.138 & 0.694 & 0.100 & -0.130 & 0.680 \\
\hline 2. & Mining & 19 & 9.09 & 13 & 7.51 & 0.148 & -0.261 & 0.700 & 0.152 & -0.268 & 0.704 \\
\hline 3. & Basic and $\mathrm{c}$ & 1 & 8.61 & 14 & 8.09 & 25 & -0.287 & 0.500 & 0.126 & 43 & 8 \\
\hline 4. & Miscellane & 7 & 3. & 7 & 4.05 & 0.218 & -0.031 & 0.500 & 0.220 & -0.032 & 0.502 \\
\hline 5. & Consumer & 8 & 3.83 & 7 & 4.05 & 0.102 & -0.108 & 0.231 & 0.105 & -0.111 & 0.234 \\
\hline 6. & $\begin{array}{l}\text { Property, real estate } \\
\text { and construction }\end{array}$ & 31 & 14.83 & 28 & 16.18 & 0.304 & -0.180 & 0.700 & 0.302 & -0.180 & 0.711 \\
\hline 7. & $\begin{array}{l}\text { Infrastructure, utility, } \\
\text { transportation }\end{array}$ & 31 & 14.83 & 20 & 11.56 & 0.193 & -0.180 & 0.700 & 0.193 & -0.185 & 0.692 \\
\hline 8. & Finance & 33 & 15.79 & 31 & 17.92 & 0.252 & -0.170 & 0.700 & 0.252 & -0.160 & 0.717 \\
\hline 9. & $\begin{array}{l}\text { Trade, service and } \\
\text { investment }\end{array}$ & 50 & 23.92 & 43 & 24.86 & 0.185 & -0.686 & 0.700 & 0.188 & -0.696 & 0.711 \\
\hline & Total & 209 & 100.00 & 173 & 100.00 & 0.181 & -0.686 & 0.700 & 0.182 & -0.696 & 0.717 \\
\hline
\end{tabular}


Table 4 presents the summary of the initial rate of return and market adjusted returns based on the type of industry (sector) of the company. The trade, services and investment sector have the largest IPO value of 50. The sector with the lowest initial return is miscellaneous with only 7 IPOs. The sector with the highest average initial return is property, real estate and construction with a value of $30.4 \%$. The sector with the lowest average initial return is agriculture, which is $9.8 \%$. Qualitatively similar findings are documented for market adjusted initial return.

\subsection{Analysis Data}

The descriptive statistics for each variable is shown in Table 5. The average IR value obtained by investors at the time of the IPO on the IDX from 2007 to 2016 is $20.2 \%$. There are a number of companies that have the highest IR value of $70 \%$. The lowest IR value is minus 69\%, which is PT. Jaya Konstruksi Manggala Pratama Tbk. The data on MAR are qualitatively similar to IR.

Table 5 Descriptive Statistics of Research Variables $(n=173)$

\begin{tabular}{lcccc}
\hline Variable & Minimum & Maximum & Mean & Std. Deviation \\
\hline IR & -0.69 & 0.70 & 0.202 & 0.274 \\
MAR & -0.70 & 0.72 & 0.203 & 0.274 \\
MBVR & 1.00 & 90.00 & 7.921 & 13.708 \\
LnTA & 22.39 & 27.26 & 25.614 & 1.561 \\
LnNPS & 21.13 & 26.47 & 24.848 & 1.334 \\
\hline Note: \\
IR = Initial Return; MAR = Market Adjusted Initial Return; MBVR = Market \\
to Book Value Ratio; LnTA = Natural Logarithm of Total Assets; LnNPS = \\
Natural Logarithm of Share Value.
\end{tabular}

The average value of a company's MBVR is 7.921. This means, on average, the price of the company's stock offer that made an IPO in the Indonesian capital market is 7.921 times their book value. The highest MBVR value is 90.00, namely PT Siloam International Hospital Tbk., and the lowest is 1.00 for PT Verena Multi Finance Tbk. 
In Table 5, it can be seen that there is a difference in information regarding the size of the company when viewed from the value of the total assets of the company's last year before making an IPO and the value of the stock offering.

Table 6 shows that the average initial return is 20.2\% with an initial market adjusted average return of $20.3 \%$. The results of the average difference test on initial return and market adjusted initial return obtained is significant $(p<\alpha)$. This shows that companies that conducted IPOs in 2007-2016 experienced underpricing.

Table 6 Test Results Differences on Average One Sample

\begin{tabular}{lcc}
\hline \multicolumn{1}{c}{ Description } & $\begin{array}{c}\text { Average Initial Return } \\
(\mathrm{p} \text {-value t-test) }\end{array}$ & Conclusion \\
\hline Initial Return & 0.202 & Underpricing \\
Market Adjusted Return & $(0.000)$ & \\
& 0.203 & Underpricing \\
\hline
\end{tabular}

Note:

IR = Initial Return; MAR = Market Adjusted Initial Return

Multiple linear regression analysis in this study aims to see how much influence the independent variable has on the dependent variable. Summary of the results of multiple linear regression analysis is presented in Table 7.

Multicollinearity test aims to test whether in the regression model there is a strong correlation between independent variables. Results of multicollinearity testing can be seen in Table 7, that there are no multicollinearity symptoms in all independent variables because each VIF values are lower than 10 .

Panel A of Table 7 shows the results of regression analysis using initial return as the dependent variable. In contrast to the initial prediction, MBVR is found to have negative coefficient of $-0.166(\mathrm{p}=0.030)$. This means MBVR is positively and significantly affecting initial return. Thus, the first hypothesis $\left(\mathrm{H}_{1}\right)$ stating the market to book value ratio has a positive effect on the level of initial return is rejected. Results on the effect of firm size on the level of initial return shows negative coefficient of $-0.100(p=0.041)$. This coefficient is statistically significant, and it is in line with the prediction. Thus, the first hypothesis $\left(\mathrm{H}_{1}\right)$ that firm size has negative effect on the level of initial return is accepted. The 
results of regression are qualitatively similar when the value of gross proceeds is used in replacement of total assets. In addition, similar results are also generated when the dependent is the market adjusted initial return (Panel B of Table 7).

Table 7 Regression Results with IR and MAR as the Dependent Variable

\begin{tabular}{|c|c|c|c|c|c|c|}
\hline Model & Prediction & $\begin{array}{l}\text { Unstandardized } \\
\text { Coefficient }\end{array}$ & $\begin{array}{c}\text { Standardized } \\
\text { Coefficient }\end{array}$ & t-stat & Sig. & VIF \\
\hline \multicolumn{7}{|c|}{ Panel A: Initial Return as the dependent variable } \\
\hline \multicolumn{7}{|c|}{$\mathrm{SIZE}=\mathrm{LnTA}$} \\
\hline Constant & & 2.762 & & 2.058 & 0.041 & \\
\hline MBVR & + & -0.166 & -0.166 & -2.192 & 0.030 & 1.042 \\
\hline LnTA & - & -0.100 & -0.156 & -2.061 & 0.041 & 1.042 \\
\hline \multicolumn{7}{|c|}{ F-stat $=5.661 ;$ Sig $=0.004 ;$ Adj. $\mathrm{R}=0.051 ; \mathrm{R}^{2}=0.062 ; \mathrm{DW}=1.901$} \\
\hline \multicolumn{7}{|c|}{ SIZE $=$ LnNPS } \\
\hline Constant & & 6.085 & & 3.899 & 0.001 & \\
\hline MBVR & + & -0.074 & -0.074 & -0.944 & 0.347 & 1.192 \\
\hline LNNPS & - & -0.230 & -0.037 & -3.903 & 0.000 & 1.192 \\
\hline \multicolumn{7}{|c|}{ F-stat $=11.379 ;$ Sig $=0.000 ;$ Adj. $R=0.108 ; \mathrm{R}^{2}=0.118 ; \mathrm{DW}=1.920$} \\
\hline \multicolumn{7}{|c|}{$\begin{array}{l}\text { Panel A: Market Adjusted Return as the dependent variable } \\
\text { SIZE = LnTA }\end{array}$} \\
\hline Constant & & 2.784 & & 2.074 & 0.040 & \\
\hline ZMBVR & + & -0.164 & -0.164 & -2.162 & 0.032 & 1.042 \\
\hline LnTA & - & -0.101 & -0.157 & -2.077 & 0.039 & 1.042 \\
\hline \multicolumn{7}{|c|}{ F-stat $=5.622 ; \operatorname{Sig}=0.004 ;$ Adj. $R^{2}=0.051 ; R^{2}=0.062 ; \mathrm{DW}=1.891$} \\
\hline \multicolumn{7}{|c|}{ SIZE $=$ LnNPS } \\
\hline Constant & & 6.086 & & 3.898 & 0.000 & \\
\hline MBVR & + & -0.072 & -0.072 & -0.918 & 0.360 & 1.192 \\
\hline LNNPS & - & -0.230 & -0.307 & -3.903 & 0.000 & 1.192 \\
\hline
\end{tabular}

F-stat $=11.298 ;$ Sig $=0.000 ;$ Adj. $\mathrm{R}^{2}=0.107 ; \mathrm{R}^{2}=0.117 ; \mathrm{DW}=1.914$

Note:

MBVR is Market to Book Value Ratio; LnTA is Natural Logarithm of Total Assets; LnGP is Natural Logarithm of Gross Proceeds.

\subsection{Discussion of Research Results}

The analysis on the level of initial return shows that on average, the IPOs in this study are underpriced as much as $20.2 \%$ when initial raw return is used. The figure is slightly larger when market adjusted return is used (20.3\%). This finding confirms previous studies in most of capital markets in the world of 
underpricing phenomenon (Ritter, 1991). Thus, on average, investors who bought the shares in the primary market will receive an average profit of $20 \%$ when they sell the shares on the first day of trading.

The study finds that MBVR has negative and significant effect on the level of underpricing of companies making IPO in IDX for 2007-2016. This finding is in contrast with the prediction that higher MBVR is related to higher risk so the initial return level shall be high. Yet, the regression coefficient is negative, which is consistent with research Gounopoulos et al. (2013) who also reported a significant negative effect.

Michaely and Shaw (1995) reported that the MBVR has a significant positive effect on the level of underpricing. Michaely and Shaw studied the United States IPOs. United States IPOs are regarded as a developed market, of which in many respects the investors are better informed than in Indonesia, which is classified as a developing country.

The results of testing the effect of firm size show a negative and significant effect on the level of initial return. Testing using the IR and MAR proxies do not change the results. The size of the company, either measured using total assets or gross proceeds from the issue, shows negative effect on the level of underpricing, either measured using raw initial return or market adjusted initial return.

The size of the company is usually associated with the uncertainty of company value. Large companies are better known by the investors than small ones. So, information about large companies is more easily obtained by investors. Large companies have low level of risk so the initial return that is acceptable to investors is also low. Conversely, information about small companies tends to be less available, making it to possess greater uncertainty, which leads to greater risk. This can increase the likelihood of underpricing, which means that the higher the initial rate of return is inherent of smaller IPO companies. The results of this study are not consistent with Bhabra and Pettway (2003), Gu (2003), Schenone (2004), and Gabriela (2013) who found that the size of the company has significant positive effect on the initial return. However, it is consistent with Yolana and Martani (2005), Bowen et al. (2008), Kristiantari (2013), and Wiguna and Yadnyana (2015) who reported negative and significant correlation.

Companies with a low stock offering value will indicate higher underpricing than companies with a high share offer value (Ritter, 1991). Emilia et al. 
(2008) showed that the value of the stock offering has a negative and significant effect on initial return. This condition indicates that size anomaly occurs during the IPO. An increase in the value of the stock offering of a company that conducts an IPO will reduce the level of initial return obtained from stocks experiencing underpricing on the first day of closing on the secondary market.

\section{Conclusion}

This study aims to determine whether the market to book value ratio and firm size determine the initial return rate for companies making IPOs in 20072016. Based on the test results, the following conclusions can be drawn. The IPOs on average experience underpricing (positive initial returns). Market to book value ratio has negative and significant effect on initial return level. This means the higher the MBVR, the lower is the level of underpricing. Firm size has a negative and significant effect on the level of initial return. This means the higher the size of the company, the lower is the value of underpricing.

Two limitations emerge in this study. First, this study does not differentiate each of the sector companies. There may be arguments that different sector may have different level of risk. This study does not take into consideration the conditions of the global financial crisis (Suprime Mortgage) in 2007-2008. The global financial crisis has caused the composite indices to weaken. So, all type of issues, either good or less good IPO companies, will be severely-affected by the crisis. Consequently, future studies are expected to be able to use the results of the study as a comparison in conducting further researches. Further studies are expected to be able to distinguish each sector of the company that conducts IPO and consider the existence of a global financial crisis.

\section{References}

Bhabra, H.S. and Pettway, R.H. 2003. IPO Prospectus Information and Subsequence Performance. Financial Review, 1 (10): 1111-1146.

Bowen, M.B., Chen, X., and Cheng, Q. 2008. Analyst Coverage and the Cost of Raising Equity Capital: Evidence from Underpricing of Seasoned Equity Offerings. Contemporary Accounting Research, 25 (3): 657-700. 
Emilia, Sulaiman, L., and Sembel, R. 2008. Faktor-Faktor yang Memengaruhi Initial Return 1 Hari. 1 Bulan dan Pengaruh Terhadap Return 1 Tahun Setelah IPO. Journal of Applied Finance and Accounting, 1 (1): 116-140. Fama, E.F. dan French, K.R. 1992. The Cross-Section of Expected Stock Returns. Journal of Finance, 47 (2): 427-465.

Gabriela, L.K. 2013. Analisis Faktor-Faktor yang Memengaruhi Initial Return Setelah Initial Public Offering (IPO). FINESTA, 1 (2): 67-72.

Gounopoulos, D., Guney, Y., and Xu, T. 2013. Conducting IPO with an SEO in Mind: Evidence from China. Presented at Multinational Finance Society Conference in Izmir.

Gu, A.Y. 2003. State Ownership, Firm Size, and IPO Performance: Evidence from Chinese "A" Share Issues. American Business Review, 21 (2):101-108.

Gumanti, T.A. 2011. Manajemen Investasi Konsep: Teori dan Aplikasi. Jakarta: Mitra Wacana Media.

Gumanti, T.A. dan Utami, E.S. 2002. Bentuk Pasar Efisien dan Pengujiannya. Jurnal Akuntansi \& Keuangan, 4 (1): 54-68.

Jogiyanto, H.M. 2000. Teori Portofolio dan Analisis Investasi. Edisi Kedua. Yogyakarta: BPFE UGM.

Kim, J.B. Krinsky, I., and Jason, L. 1993. Motives for Going Public and Underpricing: New Findings from Korea. Journal of Business Finance and Accounting, 20 (2): 195-211.

Kristiantari, I.D.A. 2013. Analisis Faktor-Faktor yang Memengaruhi Underpricing Saham pada Penawaran Saham Perdana di Bursa Efek Indonesia. Jurnal Ilmiah Akuntansi dan Humanika, 2 (2):785-811.

Loughran, T., Ritter, J.R., and Rydqvist, K. 1994. Initial Public Offerings: International Insights. Pacific-Basin Finance Journal, 2(2): 165-199.

Mar'ati, F.S. 2013. Pengaruh Firm Size Terhadap Return Saham Perusahaan Manufaktur yang Tercatat di Bursa Efek Indonesia Periode 2004-2009. Among Makarti, 6 (12): 66-79.

Michaely, R. and Shaw, W.H. 1995. Does the Choice of Auditor Convey Quality in an Initial Public Offering? Financial Management, 24 (4): 15-30.

Ritter, J.R. 1991. The Long-Run Performance of Initial Public Offering. Journal of Finance, 46 (1): 3-27. 
Schenone, C. 2004. The Effect of Banking Relationships on the Firm's IPO Underpricing. Journal of Finance, 59 (6): 2903-2958.

Spatt, C.S. and Srivastava. S. 1991. Preplay Communication, Participation Restrictions, and Efficiency in Initial Public Offerings. Review of Financial Studies, 4 (4):709-726.

Sulistio, H. 2005. Pengaruh Informasi Akuntansi dan Non-Akuntansi Terhadap Initial Return Studi: Pada Perusahaan yang Melakukan Initial Public Offering di Bursa Efek Jakarta. Presented at Indonesian Accounting National Symposium 8 Solo. Central Jawa.

Sutrisno, E.A.A. and Kusuma, K.W. 2016. Kinerja Keuangan dan Pengakuan Pasar sebagai Predictor Return Saham (Studi pada Perusahaan Indeks LQ45). E-Jurnal Manajemen Universitas Udayana, 5 (3):1742-1769.

Wiguna, I Gd.N.H. and Yadnyana, K. 2015. Analisis Faktor-Faktor yang Memengaruhi Initial Return pada Penawaran Saham Perdana. E-Journal Ekonomi dan Bisnis Universitas Udayana, 4 (12): 921-946.

Yolana, C., and Martani, D. 2005.Variabel-Variabel yang Memengarubi Fenomena Underpricing pada Penawaran Saham Perdana di BEJ Tahun 1994-2001. Presented at Indonesian Accounting National Symposium 8 Solo. Central Jawa. 
Review of Management and Entrepreneurship

Volume 02, Number 02, October 2018 